\title{
Terapii inovative în bolile genetice: Fibroza chistică
}

\author{
Elena-Silvia Shelby ${ }^{1}$, Florina Mihaela Nedelea ${ }^{2,3}$, Tanser Huseyinoglu², Relu Cocoș ${ }^{3}$, \\ Mihaela Bădina ${ }^{1}$, Corina Sporea ${ }^{1}$, Liliana Pădure ${ }^{1,4}$, Andrada Mirea ${ }^{1,4}$ \\ ${ }^{1}$ Centrul Național Clinic de Recuperare Neuropsihomotorie pentru Copii „Dr. Nicolae Robănescu“, \\ București, România \\ ${ }^{2}$ Departamentul de Genetică Medicală, Spitalul Clinic de Obstetrică și Ginecologie, „Filantropia“, \\ București, România" \\ ${ }^{3}$ Catedra de Genetică, Universitatea de Medicină și Farmacie "Carol Davila“, București, România \\ ${ }^{4}$ Facultatea de Moașe și Asistență Medicală, Universitatea de Medicină și Farmacie „Carol Davila“, \\ București, România
}

\begin{abstract}
REZUMAT
Fibroza chistică, numită și mucoviscidoză, este cea mai frecventă boală pulmonară ereditară și este produsă de mutații în gena CFTR, ce codifică un canal anionic pentru clor și bicarbonat cu rol în reglarea metabolismului bicarbonatului și sării.

În momentul de față, aproximativ jumătate din totalul pacienților cu fibroză chistică pot beneficia de terapie personalizată cu ajutorul modulatorilor, substanțe care restaurează sau îmbunătățesc funcționalitatea și stabilitatea CFTR. Mai mult, la ora actuală se află în stadiul de studiu clinic și alte tipuri de terapii, ca de exemplu terapia genică utilizând sistemul CRISP/CAS-9, oligonucleotide antisens modificate sau inserția genei sălbatice utilizând particule nanolipidice sau vectori virali. Acest articol își propune să treacă în revistă principalele tipuri de terapii aprobate sau aflate în stadiul de studiu clinic pentru tratamentul fibrozei chistice.
\end{abstract}

Cuvinte cheie: fibroză chistică, modulatori, terapie genică

\section{INTRODUCERE}

Fibroza chistică, numită şi mucoviscidoză, este o boală genetică autozomal recesivă (1), cu o prevalenţă de 1 la 2.500 de nou-născuţi şi o frecvenţă a purtătorilor de 1:25 în populaţia caucaziană (2). Este cea mai frecventă boală pulmonară ereditară (3) şi este produsă de mutaţii în gena CFTR (cystic fibrosis transmembrane conductance regulator) sau $\mathrm{ABCC} 7$ (OMIM \# 602421), situată în regiunea 7q31.2 (4), ce codifică un canal anionic pentru clor şi bicarbonat (5) localizat la nivelul membranei apicale a celulelor epiteliale a mai multe organe exocrine (6). Rolul CFTR este reglarea metabolismului bicarbonatului şi sării $(6,7)$.
La ora actuală, sunt cunoscute peste 2.000 de mutaţii patogene în gena CFTR (6), aproximativ 70\% dintre acestea constând în deleţia unui aminoacid în poziţia 508 a proteinei (mutaţia fiind numită F508del sau, folosind vechea denumire, $\Delta \mathrm{F} 508$ ), ceea ce duce la împachetarea defectuoasă a proteinei, ulterior aceasta fiind distrusă (8).

Mutaţiile patogene în gena CFTR duc la producerea de sudoare cu un conţinut crescut de sare şi de mucus vâscos, ce se acumulează la nivelul tractului gastrointestinal, cu afectarea funcţiei pancreatice (prin obstrucția ductului pancreatic ce duce la inabilitatea secreţiei enzimelor pancreatice şi a hormonilor pancreatici, cu apariţia diabetului zaharat) sau a sistemului respirator (acumularea de mucus vâscos du- 
când la obstrucţie şi inflamaţie a tractului respirator, acest teren favorizând colonizarea bacteriană şi degradarea pulmonară progresivă) $(6,9)$. Feţii cu fibroză chistică au retard de creştere intrauterină, iar la feţii de sex masculin se constată absenţa congenitală bilaterală a vasului deferent (8). Vârsta medie de supravieţuire a pacienţilor cu fibroză chistică ce primesc îngrijiri medicale este, conform Registrului Fundaţiei pentru Fibroză Chistică (The CF Foundation Patient Registry), de 47,7 ani $(6,10)$. Principala cauză de mortalitate şi morbiditate a acestor pacienţi este afectarea pulmonară $(8,11)$.

Purtătorii de mutaţii în gena CFTR au o rezistenţă naturală la toxina holerică şi la febra tifoidă, Salmonella typhi, utilizând canalul CFTR pentru a intra în celulă. Acest fenomen ar putea explica frecvenţa crescută a purtătorilor în populaţia generală (8).

\section{STRUCTURA PROTEINEI CFTR ŞI TIPURI DE MUTATTII CE POT AFECTA GENA CFTR}

Canalul CFTR este o glicoproteină din a cărei structură fac parte un motiv aminoterminal sub formă de lasou (12), mai multe unităţi transmembranare ce alcătuiesc două domenii MSD (membrane-spanning domains), şi anume MSD1 şi MSD2 (acestea formând pereții canalului, modificările lor conformaţionale ducând la închiderea şi deschiderea acestuia) $(12,13)$, un domeniu $\mathrm{R}$, a cărui fosforilare determină activitatea canalului CFTR (12-15), precum şi două domenii NBD (nucleotide binding domain), şi anume NBD1 şi NBD2, ce hidrolizează ATP cu controlul închiderii şi deschiderii canalului CFTR $(12,13)$.

După ce este produsă, proteina CFTR este împachetată, glicozilată la nivelul domeniului MSD2 şi transportată la suprafaţa celulei $(6,16)$.

În funcţie de efectul produs, mutaţiile genei CFTR se împart în 6 clase (17), notate cu cifre romane de la 1 la 6 . Astfel, mutaţiile de clasa I, în care nu este creată nicio proteină funcţională CFTR $(22 \%$ dintre cazuri), constau în mutaţii nonsens, anomalii ale situsurilor de matisare sau deleţii. ARN mesager produs de genele cu aceste mutaţii este instabil şi imediat degradat; un exemplu de mutaţii de clasă I sunt mutaţiile G542X, W1282X sau R553X $(6,16,17)$.

Transcripţia genelor cu mutaţii de clasa II duce la sinteza unei proteine CFTR, însă apar erori de împachetare a acesteia, prin urmare, ea nu poate ajunge la suprafaţa celulară ( $88 \%$ dintre cazuri). Exemple de mutaţii de clasă II sunt mutaţiile F508del, N1303K, I507del, R1066C $(6,16,17)$.

Mutaţiile de clasă III permit crearea unei proteine CFTR complete, iar aceasta ajunge la suprafaţa celulară, însă canalul nu se deschide deloc/nu se deschide corect (6\% dintre cazuri) - ,gating mutations“; un exemplu de astfel de mutaţii sunt mutaţiile G551D, G178R, G551S $(6,16,17)$.

Şi mutaţiile de clasă IV permit crearea unei proteine CFTR, aceasta ajungând la suprafaţa celulară, însă canalul nu funcţionează corect $(6 \%$ dintre cazuri) iar cantitatea de clor transportat este insuficientă; un exemplu de astfel de mutaţii sunt mutaţiile R334W, R347P, R1070W (6,17).

Mutaţiile de clasă V duc, de asemenea, la crearea unei proteine CFTR complete, funcţionale, ce ajunge la suprafaţa celulei, însă aceasta este produsă într-o cantitate insuficientă ( $5 \%$ dintre cazuri). Un exemplu de astfel de mutaţii sunt mutaţiile $3849+10 \mathrm{kbC}->\mathrm{T}$, $3272-26 \mathrm{~A}>\mathrm{G}(6,16,17)$.

Mutaţiile de clasa VI permit producţia de proteină CFTR, aceasta fiind în locaţia corespunzătoare, însă proteina are o stabilitate redusă şi este degradată rapid. Un exemplu de mutaţii de clasă VI sunt mutaţiile 1811+1.6 kb A>G, 4326del şi 4279insTC $(6,17)$.

\section{MODULATORII UTILIZAȚI PENTRU TRATAMENTUL FIBROZEI CHISTICE}

În momentul de faţă, în funcţie de tipul şi poziţia mutaţiei în gena CFTR, aproximativ jumătate din totalul pacienţilor cu fibroză chistică pot beneficia de terapie personalizată $(6,18)$ cu ajutorul modulatorilor, substanţe care restaurează sau îmbunăţesc funcţionalitatea şi stabilitatea CFTR (17). Pe baza efectului lor în modularea expresiei şi funcţiei CFTR, modulatorii se împart în 5 clase, şi anume: agenţi read-through, potenţiatori, corectori, stabilizatori şi amplificatori (17). Agenţii read-through promovează continuarea procesului de translaţie în ciuda întâlnirii unui codon-stop, cu producţia unei proteine CFTR complete; potenţiatorii au rolul de a restaura sau păstra conductibilitatea canalului CFTR, cu menţinerea sa deschisă pentru a permite transportul clorului, în timp ce corectorii restaurează împachetarea şi procesarea corectă, precum şi transportul adecvat al CFTR către membrana plasmatică (17). Stabilizatorii au rol în ancorarea corespunzătoare a CFTR la nivelul plasmalemei, cu prevenirea degradării sale de către lizozomi, iar amplificatorii cresc expresia de ARN mesager pentru CFTR cu creşterea cantităţii de proteină produsă (17).

Astfel, în cazul mutaţiilor de clasă I, ce duc la scăderea semnificativă a cantităţii de proteină CFTR produsă (6), pentru mutaţiile nonsens ce duc la apariţia de codoni stop prematuri şi codificarea unei proteine trunchiate, sunt folosiţi agenţi read-through ce suprimă terminarea translaţiei (împiedicând oprirea codificării odată ce este întâlnit codonul-stop) împre- 
ună cu inhibitori pentru calea nonsense-mediated decay (NMD), care are rolul în detectarea şi degradarea ARN-mesager ce conţine codoni stop prematuri $(6,9)$. În acest sens, au fost utilizate cu succes aminoglicozidele (ca, de exemplu, gentamicina, amikacina şi, în măsură mai mică, tobramicina), care, în urma legării la situsul A ribozomal, duc la încorporarea unui ARN de transfer alternativ, cu inserţia consecutivă a unui aminoacid aleator în poziţia codonului stop prematur şi citirea de către ribozom (read-through) a codonului stop prematur şi, în consecinţă, producţia unei proteine CFTR complete şi funcţionale (9). Singurul dezavantaj al aminoglicozidelor constă în efectele adverse ototoxice şi renale (11).

Un alt compus cu acelaşi mecanism de acţiune ca aminoglicozidele (read-through agent) este atalurenul, cu denumirea comercială Translarna (9), însă acesta nu a dovedit aceleaşi efecte benefice ca în distrofia musculară Duchenne, studiile asupra lui ca potenţială terapie fiind din acest motiv întrerupte (11).

Pentru tratamentul mutaţiilor de clasă I, s-a incercat, de asemenea, combinaţia ivacaftor (Kalydeco)/ ataluren, însă, conform unui studiu efectuat în 2020 (19), nici aceasta nu s-a dovedit eficientă. Ivacaftor este un potenţiator ce creşte durata deschiderii canalului CFTR la nivelul plasmalemei $(20,21)$, corectând astfel transportul ionilor de clor la acest nivel (24). Totuşi, ivacaftor este utilizat la pacienţii cu fibroză chistică ce au vârsta de peste 4 luni şi prezintă una dintre cele 97 de mutaţii prezentate în lista din referinţa (22).

Pentru mutaţiile de clasă II, ce constau în defecte de împachetare a proteinei, sunt folosiţi corectori (medicamente ce stimulează împachetarea corectă a proteinei CFTR astfel încât aceasta să ajungă la suprafaţa celulei), fie singuri, fie în combinaţie cu alţi modulatori $(9,16,18,19)$.

Astfel, pentru cea mai comună mutaţie responsabilă de fibroza chistică, şi anume F508del, a fost utilizată cu succes o combinaţie de corector cu potenţiator (11). Combinaţia Lumacaftor/ivacaftor, cunoscută sub denumirea comercială Orkambi, a fost aprobată de FDA pentru pacienţii cu vârstă de peste doi ani care au mutaţia F508del în stare homozigotă (aproximativ 44\% dintre pacienţii cu fibroză chistică) (23). Lumacaftor este un corector ce creşte cantitatea de CFTR la nivelul plasmalemei (23). Orkambi creşte semnificativ funcţia pulmonară şi scade numărul exacerbărilor pulmonare (23).

Tot pentru tratamentul mutaţiilor bialelice F508del, de asemenea, la încă 154 de mutaţii - prezentate în lista din referinţa (24), este folosită, la persoanele cu vârsta de peste 6 ani, combinaţia tezacaftor/ivacaftor numită Symdeko. Aceasta îmbunătăţeşte funcţia pulmonară şi are avantajul de a avea mai pu- ţine interacţiuni medicamentoase decât Orkambi $(23,24)$.

Mai mult, tot pentru tratamentul pacienţilor cu mutaţie F508del, în octombrie 2019, FDA a aprobat medicamentul numit Trikafta, o triplă combinaţie formată din elexacaftor, ivacaftor şi tezacaftor, terapia fiind produsă de Vertex Pharmaceuticals $(25,26)$. Medicamentul se adresează persoanelor cu vârsta peste 12 ani care au mutaţia F508del în stare homozigotă sau heterozigotă, precum şi persoanelor care au una dintre cele 117 mutaţii responsive la acest medicament, prezentate în lista din referinţa $(27)(25,27)$.

S-a constatat că Trikafta îmbunătăţeşte semnificativ funcţia pulmonară şi indicele de masă corporală, îmbunătățeşte nivelul clorului secretat în sudoare şi scade numărul exacerbărilor pulmonare, având efecte adverse minore, ca eritem, creşterea nivelului transaminazelor şi al bilirubinei, sau simptome pseudogripale - cefalee, rinoree, diaree sau rinită (25). Există, de asemenea, riscul de a dezvolta cataractă (25).

Elexacaftor este un corector de nouă generaţie a CFTR, în timp ce tezacaftor, aprobat de FDA în februarie 2018, este un corector de primă generaţie a structurii acestei proteine $(21,28)$. Elexacaftor facilitează transportul proteinei către suprafaţa celulei cu creşterea expresiei proteinei la acest nivel (28), în timp ce tezacaftor îmbunătăţeşte procesarea celulară a proteinei CFTR, modulând poziţia sa la nivelul plasmalemei (29). Astfel, deşi prin mecanisme de acţiune diferite (28), elexacaftor şi tezacaftor acţionează sinergic pentru a creşte expresia CFTR la nivelul membranei celulare (20). Fiecare dintre aceşti corectori, luat separat, îmbunătăţeşte funcţia pulmonară, statusul nutriţional şi calitatea vieţii (28). S-a constatat că elexacaftor, tezacaftor şi ivacaftor au efecte sinergice, combinaţia lor fiind mult mai puternică decât alte combinaţii corector-potenţiator testate anterior pentru tratamentul fibrozei chistice (30).

Pentru mutaţiile de clasă III (în care proteina ajunge la nivelul plasmalemei, însă există un defect de deschidere ce îi scade funcţionalitatea) şi IV (în care proteina ajunge la suprafaţa celulei, însă există un defect de conducere ce duce la o deschidere defectuasă şi la scăderea funcţionalităţii), sunt folosiţi potenţiatorii, medicamente ce susţin deschiderea canalului CFTR şi creşterea, astfel, a transportului de clor $(16,18,19)$.

Mai mult, se ia în considerare modularea altor canale de clor (SLC6A14, SLC6A9, ANO-1, TMEM16A) şi sodiu (ENaC, SLC9A3), hidrogen şi potasiu (ATP12A) ce ar putea restaura volumul lichidului de la suprafaţa tractului respirator, care la pacienţii cu fibroză chistică este scăzut, împiedicând astfel îndepărtarea secreţiilor respiratorii (12). 
Ivacaftor (Kalydeco) a fost aprobat de FDA (Food and Drug Administration) în ianuarie 2012 (22) pentru corecţia mutaţiei G551D (o mutaţie de clasă III), prezentă la aproximativ 5\% din totalul pacienţilor cu fibroză chistică, cu redarea funcţionalităţii canalului CFTR $(11,22)$. Acest potenţiator a demonstrat o creştere a FEVS (forced expiratory volume in one second) de $10,5 \%$, o reducere a exacerbărilor pulmonare de $55 \%$ şi o creştere a calităţii vieţii pacienţilor (11).

De asemenea, Ivacaftor a fost aprobat pentru utilizare şi la pacienţii cu mutaţii de clasă IV (ex.: Arg117His), asigurând păstrarea funcţionalităţii reziduale a CFTR $(11,22)$. In momentul de faţă, Kalydeco a fost aprobat pentru tratamentul a 38 de mutaţii, la pacienţi cu vârsta peste 6 luni (22).

În plus, a fost utilizată cu succes în îmbunătăţirea funcţiei pulmonare la aceşti pacienţi şi combinaţia de tezacaftor (corector) şi ivacaftor (potenţiator), numită Symdeko (11). Totuşi, este important de menţionat că nu toţi pacienţii cu mutaţii eligibile sunt responsivi la tratament (11).

Pentru pacienţii cu mutaţii de clasă V şi VI nu există încă terapii aprobate (18).

$\mathrm{O}$ altă categorie de modulatori sunt stabilizatorii, substanţe cu rol creşterea duratei de viaţă a CFTR prin ancorarea sa la nivelul membranei plasmatice şi prevenţia endocitozei accelerate, cu distrugerea sa rapidă la nivel lizozomal (17). În acest sens, studii pe linii celulare knock-out pentru CFTR au demonstrat că administrarea factorului de creştere hepatocitar (HGF, hepatocyte growth factor) stabilizează CFTR la nivelul plasmalemei, efectul HGF fiind semnificativ potenţat atunci când acesta este în combinaţie cu lumacaftor (17).

Un alt stabilizator ce părea promiţător pentru pacienţii cu mutaţii bialelice F508del a fost cavosonstat, acesta promovând, in vitro, stabilitatea CFTR la nivelul plasmalemei prin inhibarea S-nitrozoglutationului. Totuşi, deoarece în trialurile clinice de clasa a II-a cavosonstatul nu şi-a dovedit eficacitatea în combinaţie cu lumacaftor/ivacaftor sau cu ivacaftor, studiile clinice ale rolului acestui stabilizator în fibroza chistică au fost întrerupte (17).

În ceea ce priveşte amplificatorii, la ora actuală, nesolicaftorul se află în studii clinice, demonstrând că are capacitatea de a creşte cantitatea de CFTR cu diverse mutaţii, precum şi, în combinaţie cu lumacaftor/ivacaftor, de a restaura cantitatea necesară de CFTR la nivelul plasmalemei în linii celulare cu knock-out pentru F508del (17).

Mai mult, în combinaţie cu posenacaftor (corector) şi dirocaftor (potenţiator), s-a constatat că nesolicaftor creşte, pe linii celulare cu knockout pentru F508del, secreţia de clor până la un nivel foarte apro- piat de valorile normale. Această combinaţie este, la ora actuală, în studii clinice de fază I/II (17).

\section{TERAPIA GENICĂ PENTRU TRATAMENTUL FIBROZEI CHISTICE}

În ceea ce priveşte terapia genică pentru tratamentul fibrozei chistice, s-a încercat cu succes editarea genetică a anumitor mutaţii în gena CFTR utilizându-se sistemul CRISPR/Cas9, atât la nivelul celulelor din tractul respirator, cât şi în anumite situsuri criptice de matisare de la nivel intronic (11).

În plus, sunt în curs de dezvoltare terapii pentru mutaţiile ce implică situsurile de matisare, încercându-se fie scăderea eficienţei unui situs de matisare donor sau acceptor, fie crearea unui nou situs de matisare la nivelul unui intron (11). În acest sens, se studiază efectul oligonucleotidelor antisens (11). Spre exemplu, studii efectuate pe linii celulare şi modele murine cu knockout pentru F508del au demonstrat că eluforsen, un oligonucleotid antisens modificat, are capacitatea de a restaura funcţionalitatea CFTR (17). Un studiu efectuat pe un număr redus de pacienţi cu fibroză chistică cauzată de mutaţii bialelice F508del a arătat că acest compus a fost bine tolerat și a îmbunătăţit calitatea vieţii acestor pacienţi. În ciuda lipsei efectelor adverse semnificative, la ora actuală, trialurile clinice pentru acest compus au fost oprite (17).

Terapia genică utilizând $\mathrm{o}$ transgenă de $\mathrm{ADN}$ complementar CFTR administrată la nivelul tractului respirator utilizând vectori lipidici cationici şi vectori virali, printre care şi adenovirus, nu s-a dovedit eficientă până în prezent, fie din cauza faptului că efectele benefice ale terapiei au fost sub nivelul aşteptat, în cazul administrării utilizând vectori lipidici cationici, fie din cauza efectului tranzitoriu al inserării transgenei la nivel respirator în cazul administrării utilizând virusuri adenovirus-asociate, fie din cauza insuccesului administrării genei la nivel respirator, în cazul altor virusuri $(11,16)$. Erorile ce apar la nivelul ARN mesager sunt corectate fie prin ţintirea directă a $A R N-m$, fie prin furnizarea de ARN-m funcţional la nivel celular (31).

\section{CONCLUZII}

Dacă în secolul trecut, prognosticul pentru pacienţii cu fibroză chistică era unul sumbru, la ora actuală, aproximativ jumătate dintre aceştia pot beneficia de terapie personalizată în funcţie de tipul şi poziţia mutaţiei pe care o au în gena CFTR. Numeroasele studii aflate în derulare vor aduce noi terapii şi vor oferi, în acelaşi timp, speranţa că diagnosticul de fibroză chistică nu va mai fi o sentinţă pentru aceşti pacienţi. 


\section{BIBLIOGRAFIE}

1. OMIM \# 219700. Cystic fibrosis; CF. Available at: https://www.omim. org/entry/219700.

2. Genetics Home Reference. Cystic fibrosis. Available at: https://ghr. nlm.nih.gov/condition/cystic-fibrosis\#statistics.

3. KD Wenstrom, ML Russo. Cystic fibrosis: carrier screening. Available at: https://www.uptodate.com/contents/cystic-fibrosis-carrierscreening.

4. Mall MA, Hartl D. CFTR: cystic fibrosis and beyond. European Respiratory Journal. 2014;44:1042-1054.

5. OMIM \# 602421. Cystic fibrosis transmembrane conductance regulator; CFTR. Available at: https://www.omim.org/entry/602421.

6. Pranke I, Golec A, Hinzpeter A, Edelman A, et al. Emerging Therapeutic Approaches for Cystic Fibrosis. From to Personalized Medicine. Front Pharmacol. 2019;10:121.

7. Linsdell P. Functional architecture of the CFTR chloride channel. Mol Membr Biol. 2014 Feb;31(1):1-16.

8. The Embryo Project Encyclopedia. Cystic Fibrosis Transmembrane Conductance Regulator (CFTR) Gene. Available at: https://embryo. asu.edu/pages/cystic-fibrosis-transmembrane-conductanceregulator-cftr-gene.

9. Gambari R, Breveglieri G, Salvatori F, Finotti A, et al. Therapy for Cystic Fibrosis Caused by Nonsense Mutations, Cystic Fibrosis in the Light of New Research. 2015. Dennis Wat, IntechOpen. Available at: https://www.intechopen.com/books/cystic-fibrosis-in-the-light-ofnew-research/therapy-for-cystic-fibrosis-caused-by-nonsensemutation.

10. What Is the Life Expectancy for People with Cystic Fibrosis? Available at: https://www.healthline.com/health/cystic-fibrosis-lifeexpectancy\#life-expectancy.

11. Strug LJ, Stephenson AL, Panjwani N, Harris A. Recent advances in developing therapeutics for cystic fibrosis. Hum Mol Genet. 2018 Aug 1;27(R2):R173-R186.

12. Zhang Z, Liu F, Chen J. Molecular structure of the ATP-bound, phosphorylated human CFTR. PNAS. 2018;115(50):12757-12762.

13. Sheppard DN, Welsh MJ. Structure and function of the CFTR chloride channel. Physiol Rev. 1999;79(1 Suppl):S23-S45.

14. Morales MM, Capella MAM, Lopes AG. Structure and function of the cystic fibrosis transmembrane conductance regulator. Brazilian Journal of Medical and Biological Research. 1999;32:1021-1028.

15. Riordan JR. CFTR function and prospects for therapy. Annu Rev Biochem. 2008;77:701-26.

16. Know your CFTR mutations. A CFTR Mutation Fact Sheet. Available at: https://www.cff.org/Care/Clinician-Resources/Network-News/ August-2017/Know-Your-CFTR-Mutations.pdf.

\section{Conflict of interest: none declared} Financial support: none declared
17. Lopes-Pacheco M. CFTR Modulators: Shedding Light on Precision Medicine for Cystic Fibrosis. Front Pharmacol. 2016 Sep 5;7:275.

18. Ong T, Ramsey BW. New Therapeutic Approaches to Modulate and Correct Cystic Fibrosis Transmembrane Conductance Regulator. Pediatr Clin North Am. 2016;63(4):751-764.

19. Cystic Fibrosis Foundation. CFTR Modulator Types. Available at: https://www.cff.org/Research/Developing-New-Treatments/ CFTR-Modulator-Types/.

20. Patient Brochure - Trikafta. Available at: https://www.trikafta.com/ sites/defaultffiles/patient-brochure.pdf.

21. CFTR Modulator Types. Available at: https://www.cff.org/Research/ Developing-New-Treatments/CFTR-Modulator-

Types/\#: :text=Drugs $\% 20$ that $\% 20$ target $\% 20$ the $\% 20$ underlying,potentiators $\% 2 \mathrm{C} \% 20$ correctors $\% 2 \mathrm{C} \% 20$ and $\% 20$ amplifiers.

22. Cystic Fibrosis Foundation. List of CFTR gene mutations that are responsive to Kalydeco (ivacaftor). Available at: https://www.cff.org/ Life-With-CF/Treatments-and-Therapies/Medications/KalydecoApproved-Mutations.pdf.

23. Dickinson K, Paranjape S. Triple combination therapy for cystic fibrosis is here! Contemporary PEDS Journal. 2020;37(2):17-19.

24. List of CFTR gene mutations that are responsive to Symdeko. Available at: https://www.cff.org/Life-With-CF/Treatments-andTherapies/Medications/Symdeko-Approved-Mutations.pdf.

25. FDA approves new breakthrough therapy for cystic fibrosis. U.S. Food \& Drug Administration. Available at: https://www.fda.gov/ news-events/press-announcements/fda-approves-new-breakthroughtherapy-cystic-fibrosis.

26. Khamsi R. Cystic fibrosis outlook. Nature. 2020;583:S12-S14.

27. Cystic Fibrosis Foundation. List of CFTR gene mutations that are responsive to Trikafta. Available at: https://www.cff.org/Life-With-CF/ Treatments-and-Therapies/Medications/Trikafta-Approved-Mutations. pdf.

28. Elexacaftor. Drug Bank. Available at: https://www.drugbank.ca/drugs/ DB15444.

29. Tezacaftor. Drug Bank. Available at: https://www.drugbank.ca/drugs/ DB11712.

30. Condren ME, Bradshaw MD. Ivacaftor: a novel gene-based therapeutic approach for cystic fibrosis. J Pediatr Pharmacol Ther. 2013;18(1):8-13

31. Cystic Fibrosis: Investigational Therapies. Available at: https://www. uptodate.com/contents/cystic-fibrosis-investigational-therapies. 